\title{
NOMINATION OF NEW BIOSPHERE RESERVES IN THE ISLAMIC REPUBLIC OF IRAN
}

\author{
MAHIN GAZANI \\ Member-Secretary; Iranian National MAB Committee, Tehran, Iran
}

Proceedings of the South and Central Asian MAB Meeting of Experts on Environmental Conservation, Management and Research, Hikkaduwa, Sri Lanka 15-18 October 2002

The nature of the biosphere reserve concept is increasingly well-recognized around the world as a valuable and workable model for linking the conservation of biodiversity with sustainable development. Biosphere reserves can become theatres for reconciling people and nature, they can bring knowledge of the past to the needs of the future and demonstrate how to overcome problems of a sectoral nature at our institutions. In the future, they are meant to be a means for the people who live and work within and around them to attain a balanced relationship with the natural world and to contribute to the needs of the society as a whole, by showing a way to a more sustainable future. Thus, our selection of the nominated biosphere reserves is also based on these concepts, bearing in mind that in nominating biosphere reserves of a region, the core area is an undisturbed valuable zone designated to securely protect special places in nature. To provide a better view on the subject, a summary of Iran's land characteristics and regional specifications of the nominated biosphere reserves are explained. Iran, better known in the West until recently as Persia, is situated at one of the main crossroads linking Europe and the Middle East with Central Asia. The name 'Iran' means land of the Aryans, a reference to the country's original settlers.

\section{The Land}

The Islamic Republic of Iran, featuring characteristics of arid and semi-arid zones (85\%), humid and semi-humid regions (10\%) and in parts even a mediterranean climate (5\%), neighbours Turkmenistan, the Caspian, Azerbaijan and Armenia from the north, Pakistan and Afghanistan from the east, the Persian Gulf and the Sea of Oman from the south and Turkey and Iraq from the west. Iran has an area of about $1,648,195 \mathrm{~km}^{2}(636,000$ square miles). Dominating most of the country is the Iranian plateau, a somewhat triangular shaped plateau fringed by mountains. These mountain walls separate the narrow coastal plains bordering the Caspian Sea and the Persian Gulf from the rocky highlands and great deserts of the interior. Much of the interior plateau region, which varies in height from $300 \mathrm{~m}$ to $1830 \mathrm{~m}$ feet is dry and barren. Roughly $25 \%$ of the country's land can be farmed. 


\section{Climate}

In the central plateau region, the climate is dry and the seasons are clearly defined. Along the Caspian coast, the climate is generally warm and humid. In the Southern coastal plains, summers are extremely hot and humidity is uncomfortably high. Great differences in temperature dominating her various regions is another characteristic of Iran resulting from her diverse climatic patterns.

\section{Dena Protected Area:}

The Dena protected area is located in a biogeographical region of mixed mountains and highland systems. As the highest peak of the Zagros mountains, Dena, located in the west of the country, is itself designated as the core area. From three directions of north, west and east, Dena is linked to rivers, including Khersan and Boshar, originating from its peaks. Mount Zagros, with Dena as its highest peak, has a diverse plant coverage and consequently a rich wildlife. Dena's valuable species guarantee the ecosystem's food chain. Selecting Dena as a biosphere reserve indicates the importance attached to the conservation of mountainous ecosystems. Dena is a greatly tolerant structure with strong economic and political backing. In this protected area, socio-cultural parameters create the grounds for basic, applied and operational research, and training of manpower at all levels. Locals of this region (the Ghashghaie nomads) have for centuries lived on the region's industries such as fish culture, tourism, hunting, grazing, agriculture, etc.

\section{Hamoun Protected Area:}

Hamoun is located in the Sistan watershed area in the east of the country. The main reason for its nomination as a biosphere reserve is to conserve biological diversity and the genetic resources of the Hamoun Wetlands, (Hamoun-e-Poozak and Hamoun-e-sabery), as the habitat of hundreds of thousands of local and emigrant marine birds, and to provide the means of employment for the region's locals. Recent political problems due to its location along the Iran-Afghan border, which have led to excessive utilization of the waters entering the wetland, have greatly endangered it even to the extent of drying. Restoration of managed ecosystems in order to attain their lost primary natural conditions is another main objective for the introduction of the Hamoun biosphere reserve. Organizing and promoting coordinated multilateral research between the two states regarding conservation of biological diversity, evaluation of the impacts of unequal advanced and traditional land use upon the ecosystem of the wetland, introduction of common sustainable systems in managed lands, promotion and organization of educational activities in various fields of environment, education and training of eligible human resources and encouragement of local societies to participate in the management of biosphere reserves, are also among the main objectives of Hamoun's introduction as a biosphere reserve. 


\section{Bakhtegan National Park and Wildlife Refuge:}

Bakhtegan collection of national park and wildlife refuge consists of mountainous regions and marine ecosystems (Tashk and Bakhtegan lakes) which together create a unique landscape. The Neiriz and Kamjan lakes are among those internationally recognized wetlands registered in the Ramsar site conventions. In line with the protection of important ecological processes and life systems of natural core areas of the region as endemic centres rich in genetic resources, conservation of marine and mountainous ecosystems is deemed indispensable. Utilization of wild specimens of forest relatives (such as in areas under Ficus carica and cotton cultivation) is a great aid to conservation programmes of genetic resources in natural conditions. It is deemed essential for the managerial programme that the above mentioned programme in the region is promoted and developed.

\section{Central Alborz Protected Area:}

This region is part of the coastal forests remaining from the Jurassic period and an indicator of those valuable dry and coastal environments requiring special protection. Some thirty years ago regardless of their economic potentials Iranian forests covered an area of eighteen million hectares, whereas nowadays, this figure has fallen to less than ten million hectares. There has been a remarkable decrease in the size of Northern Iranian forests, due to an increase in population, transformation and development of agricultural lands, and excessive use of resources. The woods along the coast of the Caspian are considered as the only trade and industrial forests of the country. Over thirty years ago, these forests had covered an area larger than 3.6 million hectares, which has now decreased to less than one million hectares. Grazing and certain agricultural activities and over-utilization are considered the main factors involved in the destruction of Iran's northern forests. Over 600,000 people and about $100,000,000$ cattle, live in and depend on these forests. Apart from the mentioned population, more than $1,000,000$ people also live in villages adjacent to these forests, relying on them for fuel and forage. Even though these forests are vital to people, they are not so keen on participating in their revival, restoration and improvement. Long term ownerships, excessive utilization and unlimited use of forest resources regardless of sustainable development, are considered the primary factors endangering the forests. The trend of destroying Northern Iranian forests as natural habitats, has greatly influenced the lives of its related wildlife. Thus; this change in the conditions of their habitats has made the wildlife species less compatible with their surroundings, thus threatening them with extinction. For example, one may refer to the extinction of the Caspian Tiger from these forests, during the last fifty years. Therefore, it is vital that these forests be protected. 


\section{Lisar Protected Area:}

The Lisar protected area, located in the western coast of the Caspian, consists of sub-tropical and temperate rainforests which continue to the Neor Heights, and the beautiful Lake Neor at the top is noted as the area's main feature. Being part of the Caspian forests is a commonality this region shares with the Central Alborz Protected Area, and their specific importance, both at a regional and international level, is noteworthy.

\section{Shadegan Wildlife Refuge:}

The Shadegan Wildlife Refuge is located at the head of the Persian Gulf and is known as one of the most important international wetlands. This wetland acts as a refinery for the Karoon River. Waste produced from the development of agricultural industries, specifically the sugar cane industry in southwest Iran, and residue of substances used in agricultural activities enter Shadegan Wetland and prevent the pollution of the Karoon River which flows directly into the Persian Gulf. This area which is a part of the Persian Gulf plateau ecosystem and wetland region, is the gathering place for a great number of local and emigrant birds, including Marmaronetta angustirostris, Numenius arquata, Pelecanus crispus and Aythya nyroca. Due to the rapid development of industries in the wetland's marginal areas, excessive use of water resources and a resultant change in land use, Shadegan has become the focus of great international attention, and according to the Ramsar convention provisions, it is considered as one of the world's endangered wetlands.

\section{Nayband Protected Area:}

It is a coastal ecosystem with Mangrove forests surrounding the region in parts. Encumbered mainly by hills, plains and sea, this region is a biogeographical system of warm, semi-desert and coral reef. Nayband Gulf is located to the west of the Persian Gulf region. The Mangrove forests, known as a mothering place for marine and wildlife, are greatly endangered, due to pollution and over-utilization of resources (as a result of the establishment of the Southern Pars site in this area). These forests resemble great towers protecting coastal areas from erosion. Given the various products obtained from them, marine societies have long been at the service of human communities. A certain specimen of fish known as Sangsar is also reported to be a primary source of revenue for the local people, hence the destruction of its habitat has adverse effects on the lives of the marginal societies.

\section{Khosh Yeilagh Wildlife Refuge:}

This region is located between the Iranian desert and the deciduous forests of the Caspian. From 1967, the region has been under the management of the Department for Environment, first as a protected area and now as a refuge for wildlife. Khosh 
Yeilagh covers an area of $143,000 \mathrm{ha}$. As a protected area and thus due to limitation in human activities, it enjoyed very good natural conditions. The importance of this wildlife refuge is of such an extent, that it was named the Asian Serenghitti by world organizations owing to its rich biodiversity. During the years 1975-1977, the region's population of wild goat and sheep (Capra hyrcus) reached 12,000. In 1978, the sudden advent of cattle raisers to the region and excessive pressure on the rangelands caused by over-grazing, led to severe damage and irreparable destruction of these lands. Long term over-grazing, bush, shrub and tree pickings, illegal hunting and the presence of sheep-dogs are considered as the primary factors for the destruction and insecurity in the region. Therefore, in order to save the region, onefifth of the land is defined as the core area and are under special management and protection. The existence of more than 120 sheep-folds in which more than 8,000 heads of livestock are kept, calls for full national and international support to rehabilitate this natural habitat. Determining the carrying capacity of the rangelands during the grazing season is yet another important action to be taken in this respect.

\section{Fereydoonkenar Wildlife Refuge:}

As a refuge for wildlife, this area has been under the management and protection of the D.o.E since 1974. It owes its fame to the presence of migrant birds, that is to say, Fereydoonkenar hosts large flocks of these birds on their way from Siberia to Gilan in Iran, as a place for overwintering. The region is in fact a wetland, and in local dialect called, Lapou-ye-Fereydoonkenar. Due to sedimentation and transfer of a large amount of soil from lands under cultivation, the size of the wetland has been reduced to a large extent. Water stored in the wetland during winter is used by the farmers in farming seasons (Spring and Autumn). Given the importance of this region as a site for overwintering of birds, such as Gallinula chloropus and Sterna sp., any change in their habitat has adverse effects on their migration and may even cause them to perish. Uncontrolled hunting is also among the primary factors endangering this region. Its core has an area of $90 \mathrm{ha}$, and together with its buffer and transition zones, the wetland's area adds up to 3,000ha. Its small core area (90ha), provides the grounds for the wise management of the wetland's resources which are excessively used by the rural communities. Thus protection of its valuable genetic resources is deemed possible.

Management of the region's resources aims at two main objectives:

- Dredging of the wetland

- Rehabilitation of areas under abuse by the locals 


\section{Gamishloo Wildlife Refuge:}

In Iran, natural resources and their wildlife are greatly endangered. Nature is not always able to restore its losses and reach equilibrium, unless there is a balance in its use. Gamishloo Wildlife Refuge has an area of 85,000ha and is located in the northwest of Isfahan.

The name Gamishloo means land of straws (Strawland), referred to as Neyzar in the local dialect. This refuge is considered as one of the most important regions in Central Iran and is a rich genetic resource of the country. It is suitable winter quarters for sub-species of Isfahan Ovis orientalis and a place for overwintering of migrant cattle from adjacent regions such as Charmahal-o-Bakhtiari. Recreation values, spectacular landscapes, stocks of wild goat and sheep (Capra hyrcus), Ovis orientalis and Gazella sp., numerous springs, ancient monuments, rich flora and fauna and the region's educational, research, scientific, cultural and recreational facilities, are primary reasons for the nomination of this region as a biosphere reserve. The most important factors causing destruction in this region include inadequate recognition of the region's capacities, biological potentials and level of tolerance against unnatural activities.

\section{Bahookalat Protected Area:}

This region, located in southeast Baloochestan near the Iran-Pakistani border, has an area of $394,750 \mathrm{ha}$, and consists of Bahookalat and parts of Sarbaz and Kajoo rivers. It also includes the Govater Gulf and Hour-e-Bahou, located in the Sea of Oman in the south of Iran. Bahookalat $(313 \mathrm{~km})$ and Kajoo $(220 \mathrm{~km})$ rivers, together with their waterways, are the best and only habitat for the Iranian Crocodilus palustris. An earth dam called Pishin has been constructed on Bahookalat River.

The region's water for farming is provided from the detour dam of Shirkuaz, in the Shirkuaz site, constructed below the Pishin Dam.

\section{Tandooreh National Park and Protected Area:}

It is an arid mountainous region located in northeast Iran with an area of $35,500 \mathrm{ha}$, 1,900ha of which is chosen as the core area and the rest makes up its buffer and transition zones. This region was nominated a protected area in 1968 and a national park in 1969. The region's limits, except its northern frontier; are clearly defined by mountains and roads. The neighbouring farming lands in the north have obliterated its northern frontier. The existence of about 500 wild goats and sheep (Capra hyrcus and Ovis orientalis) indicates the region's security, despite severe winds characteristic of this region. Preventing cattle from grazing in the national park has improved the conditions of this region to reach ecological balance during recent years. Among its main flora, one can refer to Juniperus excelsa which 
regenerates in this region more than in any other place. Phasianus colchicus and Panthera pardus among the fauna are also found in the Tandooreh National Park.

\section{Tang-e-Sayad National Park and Protected Area:}

This region has an ecosystem of mixed mountains and a highland system; with a total area of 27,224 ha where the size of its core area is 4,097ha. A diverse plant coverage including Astragalus sp., Equisetaceae, Gundelia sp., Rheum sp., Amygdalus sp., Vitis sp. and Ficus carica, as its main flora, is a characteristic of Tang-e-Sayad. Its main fauna consist of Capra hyrcus, Ovis orientalis, Panthera pardus, Canis lupus and Felis silvestris. Ammopedrix griseogularis, Alectoris chukar and Tetragallus caspius are birds most seen in this region.

\section{Govater Gulf:}

As an important gulf of the Oman Sea, Govater, located to the southeast of the Bahookalat region has a total area of $270 \mathrm{ha}$. The gulf is the habitat of various species of phytoplankton. Avicennia marina, Tamarix sp. and Salsola sp. are known as its main flora, and Ardea cinerea, Falco pelegrinoides and Falco pregrinus are among its main fauna.

We wish these explanations to be of use in your assessments of our newly introduced biosphere reserves and in solving one of the most important questions the world faces today, which is how to reconcile conservation of biodiversity and biological resources with their sustainable use.

\section{Futher information on the 14 biosphere reserves}

\section{Dena Protected Area:}

Country: I.R of Iran

Location: $36 \mathrm{~km}$ from Yasuj; North of Kohkiloyeh va Boyerahmad (province between this province and Isfahan)

Latiudes and longitudes: $51^{\circ} 37^{\prime} 22^{\prime \prime} 51^{\circ} 09^{\prime} 01^{\prime \prime}$

$30^{\circ} 51^{\prime} 42^{\prime \prime} 31^{\circ} 12^{\prime} 17^{\prime \prime}$

Size and spatial configuration:

Size of total area: $89,192 \mathrm{ha}$

Size of core area: $35,300 \mathrm{ha}$

Size of buffer zone: $53,892 \mathrm{ha}$

Biogeographical region: mixed mountain and highland system.

Altitude: Highest elevation above sea level: $4,425 \mathrm{~m}$

Lowest elevation above sea level: $1,300 \mathrm{~m}$ 


\section{Main species and endangered and threatened plants:}

Quercus sp., Juniperus excelsa, Amygdalus lycioides, Fraxinus excelsior, Pistacia mutica, Salix alba, Tamarix sp.,

\section{Main fauna:}

Ursus arctos, Vulpes vulpes, Panthera pardus, Sus scrofa, Capra hircus, Ovis orientalis,

Birds:

Upupa epops, Alectoris chukar, Ammoperdix griseogularis.

\section{Hamoun Protected Area:}

Country: I.R of Iran

Location: This region is located in the Sistan watershed area in the east of the country. Hamoun-E-Poozak and Hamoun-E-Sabery are located along the Iran - Afgan border.

Latitudes and longitudes: $60^{\circ} 56^{\prime} 00^{\prime \prime} 61^{\circ} 48^{\prime} 00^{\prime \prime}$

$30^{\circ} 21^{\prime} 00^{\prime \prime} 31^{\circ} 27^{\prime} 00^{\prime \prime}$

Size and spatial configuration:

Size of total area: $293,030 \mathrm{ha}$

Size of core area: $25,000 \mathrm{ha}$

Size of buffer zone: 268,030 ha

Altitude: Highest elevation above sea level: $490 \mathrm{~m}$

Lowest elevation above sea level: $470 \mathrm{~m}$

\section{Main fauna:}

This region is the habitat of 185 species of birds.

Aythya nyroca, Marmaronetta angustirostris, Pelecanus crispus, Pelecanus onocrotalus,

Mammals:

Canis lupus, Felis chaus, Felis silvestris,

Main flora:

Tamarix sp., Typha sp., Phragmites sp. 


\section{Economic activities:}

As a genetic reserve of the Hamoun lake area, the Hamoun Wetland has generated employment opportunities to a great number of local people. Fishing and bird hunting have long satisfied the protein needs of the region.

\section{Bakhtegan National Park and Wildlife Refuge:}

This complex is located in the east, $100 \mathrm{~km}$ from Shiraz and to the West and North of Neiriz and Estahbanat towns respectively, in the Fars Province.

Latitudes and longitudes: $53^{\circ} 12^{\prime} 50^{\prime \prime} 54^{\circ} 12^{\prime} 09^{\prime \prime}$

$29^{\circ} 11^{\prime} 49^{\prime \prime} 29^{\circ} 49^{\prime} 25^{\prime \prime}$

Size and spatial configuration:

Size of total area: 360,404 ha

Size of marine core area: $160,000 \mathrm{ha}$

Size of buffer area: 200,404ha

Altitude: Highest elevation above sea level: $2,950 \mathrm{~m}$

Lowest elevation above sea level: $1,558 \mathrm{~m}$

Biogeographical region: Mixed mountain and highland system.

Tashk and Bakhtegan lakes, various islands situated in these lakes, and mountainous regions, along with a capillary like network of rivers, are among the beautiful areas under protection of the link organization.

\section{Main flora:}

At the edge of lakes are the halophyte splants, and in dryland the plant cover mostly includes:

Juniperus excelsa, Pistacia mutica, Amygdalus lycioides,

\section{Wildlife:}

Marine birds:

Pelecanus sp., Phoenicoplerus ruber, Anser sp., Ardea cinerea, Grus grus,

Birds: Alectoris chukar, Chlamydotis undulata, Coturnix coturnix,

Hunting birds:

Aquila sp., Gyps fulvus, Circus sp., Falco peregrinus, Falco cherrug,

Mammals:

Hyaena hyaena, Vulpes vulpes, Canis aureus, Ovis orientalis, Capra hircus,

Fishes:

Cyprinus carpio, Capoeta capoeta. 


\section{Central Alborz Protected Area:}

This region is located to the north of Tehran between Mazandaran and Tehran Provinces and bounded by the following towns: Tehran, Shemiranat, Karaj, Chalous, Noshahr and Noor.

Latitudes and longitudes: $51^{\circ} 02^{\prime} 11^{\prime \prime} 52^{\circ} 01^{\prime} 16^{\prime \prime}$

$35^{\circ} 46^{\prime} 34^{\prime \prime} 36^{\circ} 39^{\prime} 31^{\prime \prime}$

Size and spatial configuration:

Size of total area: $410,789 \mathrm{ha}$

Size of core area: 26,500 ha

Size of buffer zone: 384,289 ha

Biogeographical region: Mixed mountain and highland system and sub-tropical and temperate rainforests.

\section{Main flora:}

Buxus hyrcana, Gleditsia caspica, Albizia julibrisin, Parotia persica, Carpinus betulus,

\section{Wildlife:}

Mammals:

Panthera pardus, Ursus arctos, Canis aureus, Vulpes vulpes, Canis lupus, Martes foina, Meles meles,

Marine:

Cyprinus carpio,

Birds:

Alectoris chukar, Tetraogallus caspinus, Order-Passeriformes,

Hunting birds:

Aquila sp., Gypaetus barbatus, Accipiter gentilis, Falco tinnunculus.

\section{Lisar Protected Area:}

This region is located within the boundries of Astara and Hashtpar, in the provinces of Gilan and Ardabil.

Latitudes and longitudes: $48^{\circ} 32^{\prime} 51^{\prime \prime} 48^{\circ} 56^{\prime} 10^{\prime \prime}$

$37^{\circ} 52^{\prime} 48^{\prime \prime} 38^{\circ} 02^{\prime} 27^{\prime \prime}$

Size and spatial configuration:

Size of total area: 31,044 ha

Biogeographical region:

Sub-tropical and temperate rainforests. 


\section{Main flora:}

Fagus orientalis, Carpinus betulus, Diospyrus kaki, Quercus sp., Alnus sp.,

\section{Main fauna:}

Ursus arctos, Capra hircus, Sus scrofa, Cervus elaphus, Capreolus capreolus, Lepus capensis,

Birds:

Tetraogallus caspicus, Phasianus colchicus.

\section{Shadegan Wildlife Refuge:}

The Shadegan Wildlife Refuge is located at the top of the Persian Gulf in the Ahvaz Province, $10 \mathrm{~km}$ from Abadan.

Latitudes and longitudes : $48^{\circ} 18^{\prime} 25^{\prime \prime} 49^{\circ} 03^{\prime} 38^{\prime \prime}$ $29^{\circ} 59^{\prime} 54^{\prime \prime} 30^{\circ} 44^{\prime} 07^{\prime \prime}$

Size and spatial configuration:

Size of total area: 327,764 ha

Size of core area: 51,900 ha

Size of buffer zone: 275,864 ha

Biogeographical region:

Warm desert and semi-desert, also Wetland.

\section{Main flora:}

Cyperus sp., Typha sp.,

\section{Main fauna:}

Marmaronetta angustirostris, Ciconia sp., Nimenius sp., Tringa sp., Aythya nyroca, Pelecanus crispus.

\section{Nayband Protected Area:}

Latitudes and longitudes: $52^{\circ} 34^{\prime} 27^{\prime \prime} 52^{\circ} 51^{\prime} 39^{\prime \prime}$

$$
27^{\circ} 14^{\prime} 07^{\prime \prime} 27^{\circ} 24^{\prime} 04^{\prime \prime}
$$

Size and spatial configuration:

Size of total area: 16,919 ha

Size of core area: 7,500 ha

Size of buffer zone: 9,419 ha

Biogeographical system:

Warm desert and semi-desert and Coral reefs. 
Altitudes: Highest elevation above sea level: $138 \mathrm{~m}$

Lowest elevation above sea level: $8 \mathrm{~m}$

Climate:

Average minimum temperature during the coldest month: $5-8^{\circ} \mathrm{C}$

Maximum temperature: $50^{\circ} \mathrm{C}$

Minimum temperature: $6^{\circ} \mathrm{C}$

Average annual rainfall: $94.28 \mathrm{~mm}$

Main fauna:

Alectoris chukar, Chlamydotis undulata, Ammoperdix griseogularis, Ardea cinerea.

\section{Economic activities:}

Fishery is important in this region due to protection of certain economic species of fish (Sangsar). Other attributes of the region are access to education, research, ecotourism, and permanent monitoring capacities.

\section{Khosh Yeilagh Wildlife Refuge:}

Latitudes and longitudes: $55^{\circ} 14^{\prime} 44^{\prime \prime} 56^{\circ} 38^{\prime} 20^{\prime \prime}$

$$
36^{\circ} 38^{\prime} 20^{\prime \prime} 37^{\circ} 02^{\prime} 38^{\prime \prime}
$$

Size and spatial configuration:

Size of total area: $143,146 \mathrm{ha}$

Size of core area: $36,200 \mathrm{ha}$

Size of buffer area: 106,946ha

Biogegraphyical system:

Mixed mountain and highland system.

\section{Main flora:}

In the desert:

Family:Poaceae, Artemisia sp., Zygophyllum sp., Haloxilon sp.,

In the forest:

Quercus sp., Quercus castanifolia, Carpinus betulus, Fraxinus excelsoir, Juniperus excelsa,

\section{Main fauna:}

In the forest:

Ovis orientalis, Capra hircus, 
In the desert:

Panthera pardus, Capra hircus, Capreolus capra, Cervus elaphus, Canis lupus, Gazella subgutturosa.

\section{Tandooreh National Park and Protected Area:}

The Tandooreh Complex is located in the north-east of Iran to the north of the Khorasan Province and between Ghoochan and Dareh Gaz.

Latitudes and longitudes: $58^{\circ} 33^{\prime} 48^{\prime \prime} 58^{\circ} 54^{\prime} 27^{\prime \prime}$.

$$
37^{\circ} 19^{\prime} 41^{\prime \prime} 37^{\circ} 31^{\prime} 58^{\prime \prime}
$$

Size and spatial configuration:

Size of total area: $35,540 \mathrm{ha}$

Size of core area: $1,900 \mathrm{ha}$

Size of buffer zone: $33,640 \mathrm{ha}$

Altitudes: $3,000 \mathrm{~m}$

Up to now 425 plants and 45 mammal species have been identified in this region.

\section{Main flora:}

Juniperus excelsa, Acer monspessulanum, Cotoneaster discolor, Ferula sp.,

\section{Main fauna:}

Mammals:

Ovis orientalis, Capra hircus, Panthera pardus, Felis silvestris, Canis aureus,

Birds:

Ammoperdix griseogularis, Alectoris chukar; Phasianus cuichicus, Columba sp.

\section{Tang-E-Sayad National Park and Protected Area:}

Latitudes and longitudes: $50^{\circ} 58^{\prime} 04^{\prime \prime} 51^{\circ} 10^{\prime} 31^{\prime \prime}$

$$
32^{\circ} 03^{\prime} 03^{\prime \prime} 32^{\circ} 17^{\prime} 15^{\prime \prime}
$$

Size and spatial configuration:

Size of total area: $27,224 \mathrm{ha}$

Size of core area: $4,097 \mathrm{ha}$

Biogeographical region:

Mixed mountain and highland system.

Altitudes: Highest elevation above sea level: $3,136 \mathrm{~m}$

Lowest elevation above sea level: $2,200 \mathrm{~m}$ 


\section{Main flora:}

Astragalus sp.,

Family: Equisetaceae

Gundelia sp., Rheum sp., Amygdalus sp., Vitis sp., Ficus carica,

\section{Main fauna:}

Capra hyrcus, Ovis orientalis, Panthera pardus, Canis lupus, Felis silvestris,

Birds:

Ammoperdix griseogularis, Alectoris chukar, Tetraogallus caspius.

\section{Fereydoonkenar Wildlife Refuge:}

This wetland is located in south-east of the Caspian Sea, 30km from Fereydoonkenar City in the Mazandaran Province.

Latitudes and longitudes: $52^{\circ} 33^{\prime} 40^{\prime \prime} 52^{\circ} 34^{\prime} 30^{\prime \prime}$

$36^{\circ} 40^{\prime} 15^{\prime \prime} 36^{\circ} 40^{\prime} 33^{\prime \prime}$

Size and spatial configuration:

Size of total area: $46 \mathrm{ha}$

Altitude: $20 \mathrm{~m}$

\section{Economic activities:}

Bird hunting - rice cultivation

\section{Main flora:}

Carpinus betulus, Fraxinus excelsior, Pterocarya fraxinifolia, Cynodon sp., Cyperus sp.,

\section{Main fauna:}

Anas platyrhychos, Anas crecca, Anas clypeata, Anser anser, Grus leucogeranus, It is the best habitat for overwintering for the Siberian Crane.

\section{Gamishloo Wildlife Refuge:}

Wildlife Refuge is located in the northwest of Isfahan in the Isfahan Province 15km from Tiran City.

Size and spatial configuration:

Size of total area: $86,892 \mathrm{ha}$

Size of core area: $13,355 \mathrm{ha}$ 
Size of buffer zone: 73,537 ha

Latitudes and longitudes: $51^{\circ} 48^{\prime} 51^{\circ} 00^{\prime}$

$$
32^{\circ} 05^{\prime} 33^{\circ} 05^{\prime}
$$

Average temperature during the warmest month: $41.5^{\circ} \mathrm{C}$

Average temperature during the coldest month: $-18.5^{\circ} \mathrm{C}$

Highest elevation above sea level: $2,750 \mathrm{~m}$

Average elevation above sea level in the eastern region: $1,700 \mathrm{~m}$

Average elevation above sea level in the western region: $2,100 \mathrm{~m}$

Biogeographical region:

Cold winter (Continental) desert and semi-desert.

\section{Main flora:}

Allium bungei, Demavandia pstinacifolia, Silen gynadioica, Trigonella eliptica,

\section{Main fauna:}

Birds:

Corvus corona, Sylvia nana, Columba livia, Turdus philomelos,

Reptiles:

Coluber najadum, Telescopus fallax, Pseudocerastes persicus, Mabuya aurata.

\section{Bahookalat Protected Area:}

Hoor-E-Govater is located to the southeast of Baloochestan, near the Iran-Pakistan border $85 \mathrm{~km}$ to the east of Chabahar.

Size and spatial configuration:

Size of total area: 33,400 ha

Latitudes and longitudes: $61^{\circ} 30^{\prime}$

Biogeographical region:

Warm desert and semi-desert.

Altitude: $50 \mathrm{~m}$

\section{Economic activities:}

Fishing, Farming and Grazing.

\section{Main fauna:}

Crocodylus palushis palustris, Testudo graeca zarudnyi, Cheloniamydas japonoca,

Fishes:

Cyprinion milesi,Cyprinion eatsoni, 
Mammals:

Sus scrofa, Hyaena hyaena, Canis aureus,

Birds:

Gyps bengalensis, Athene brama, Saxicola caprata,

\section{Main flora:}

Avicennia marina, Nerium indicum, Typha sp.

\section{Govatr Gulf:}

Govater Gulf is located to the southeast of the Bahocalat region and is considered as one of the most important gulfs of Oman Sea.

Latitudes and longitudes: $61^{\circ} 24^{\prime} 00^{\prime \prime} 61^{\circ} 46^{\prime} 00^{\prime \prime}$

$$
25^{\circ} 11^{\prime} 00^{\prime \prime} 25^{\circ} 01^{\prime} 00^{\prime \prime}
$$

Size and spatial configuration:

Size of total area: 270 ha

There exist 93 species of phytoplankton in the Gulf including:

Pyrophyta 28 species

Bacillariophyta 63 species

Cyanophyceae 2 species

\section{Main flora:}

Avicennia marina, Tamarix sp., Salsola sp.,

\section{Main fauna:}

Ardea cinerea, Falco pelegrinoides, Falco pregrinus, 